\title{
Which Country Is the Largest Oil Producer in the World - the USA, Russia or Saudi Arabia: The Question of Measurement - What and How
}

\section{Eugene Khartukov}

Department of Management and Marketing, Moscow State Institute, University for International Relations (MGIMO MFA), Moscow, Russia

\section{Email address:}

khartukov@gmail.com

\section{To cite this article:}

Eugene Khartukov. Which Country Is the Largest Oil Producer in the World - the USA, Russia or Saudi Arabia: The Question of Measurement - What and How. American Journal of Energy Engineering. Vol. 9, No. 1, 2021, pp. 8-18. doi: 10.11648/j.ajee.20210901.12

Received: January 11, 2021; Accepted: February 17, 2021; Published: March 26, 2021

\begin{abstract}
Current and past statuses and dynamics of oil production and methods of oil measurements in different countries under different temperatures and preassures - are considered and analyzed. The author uses methods of comparative and systematic analyses, which are implemented for assessing oil production in the USA, Saudi Arabia and Russia - the world's leading oil producers - and globally (in the world's context) in the past, currently and in the foreseeable future (throughout 2050). Crude oil and field (crude + lease NGLs) are considered. Oil developments in the USA, Saudi Arabia and Russia are analyzed separately with their main oil fields being covered. In the past a status of the world's largest oil producer was taken in rotation by Russia and Saudi Arabia. Before 1992 the world supremacy in oil belonged to Russia but afterwards and until 2014 - mainly to Saudi Arabia. The article mainly concludes that now (since 2014) the USA produce more oil (crude oil + field condensate) than any other country of the world, even without accounting for indigenous biofuel liquids and mostly thanks to the massive tight-oil production.
\end{abstract}

Keywords: Crude Oil, Natural Gas Liquids/Condensate, Temperature, Pressure, STP, The USA, Russia, Saudi Arabia

\section{Introduction}

It is widely accepted that the current top oil producers are the USA, Russia and Saudi Arabia, which produced all together in
2019 some two fifths of the world's field production of oil (that is of the global crude oil and lease conden-sate output) (Figures 1-3), but there are some nuances... (see below).

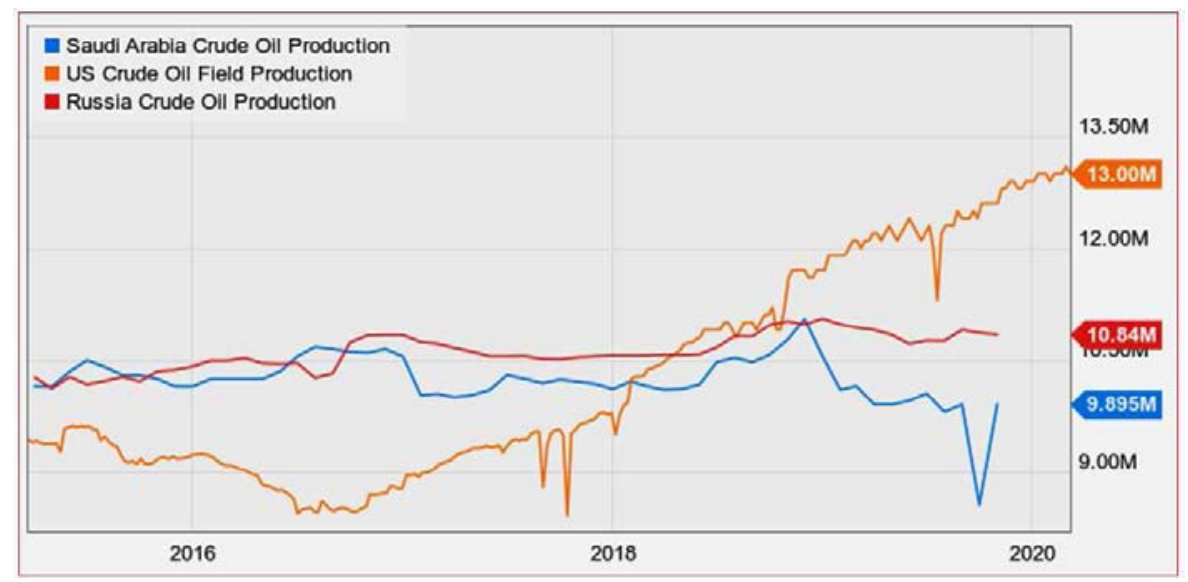

Figure 1. Monthly Oil Production in Russia, the USA and Saudi Arabia in 2011-2019, in mln b/d [1]. 


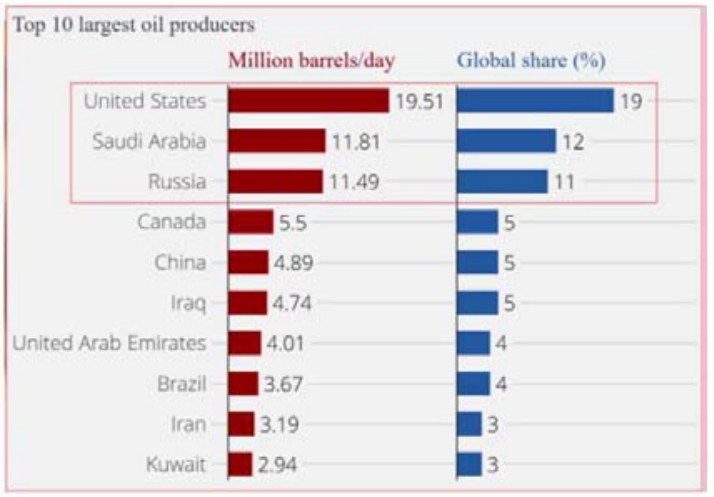

Figure 2. Oil Production (in $\mathrm{mln}$ b/d) in the USA, Russia and Saudi Arabia and Shares of These Producers in Global Oil Supply (in \%\%) in 2019.

Source: Ten largest oil producers

https://www.valuewalk.com/2020/06/largest-oil-producers-2020 [2]

Individually speaking, Saudi Arabia is not king of the oil production hill, for its nemesis - the country that sought to undo every production quota OPEC could come up with, is the United States. On its own, the United States produced 19.51 million barrels of oil (and other petroleum liquids) per day, besting both Saudi Arabia and Russia, and controlling $19 \%$ of the world's oil supplies (Figure 3).

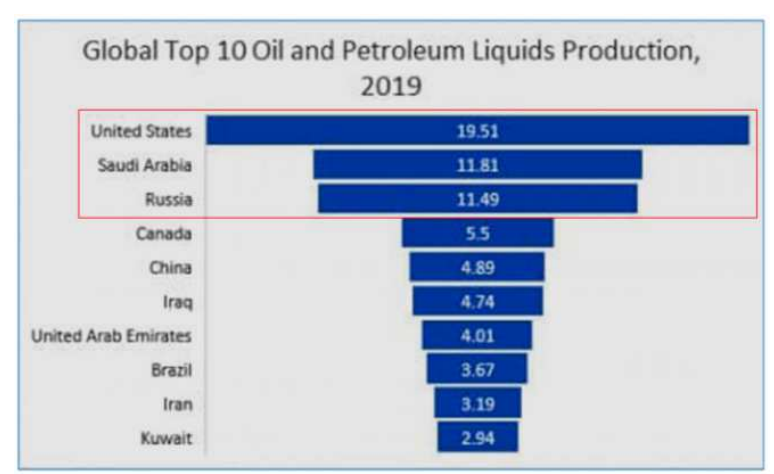

Source: https://oilprice.com/Energy/ Crude-Oil [3]

Figure 3. Field Oil Production in the USA, Saudi Arabia and Russia in 2019, in $\mathrm{mln} b / d$.

In its turn, the highly reliable statistics of BP (with actual annual data for 2020 being expected only in June-July 2021) tell that the USA, Russia and Saudi Arabia produced in 2019 746.7, 568.1 and $556.6 \mathrm{mln}$ tonnes of crude oil and other oil liquids (NGL) correspondingly (or nearly $42 \%$ as a total) (Figure 4).

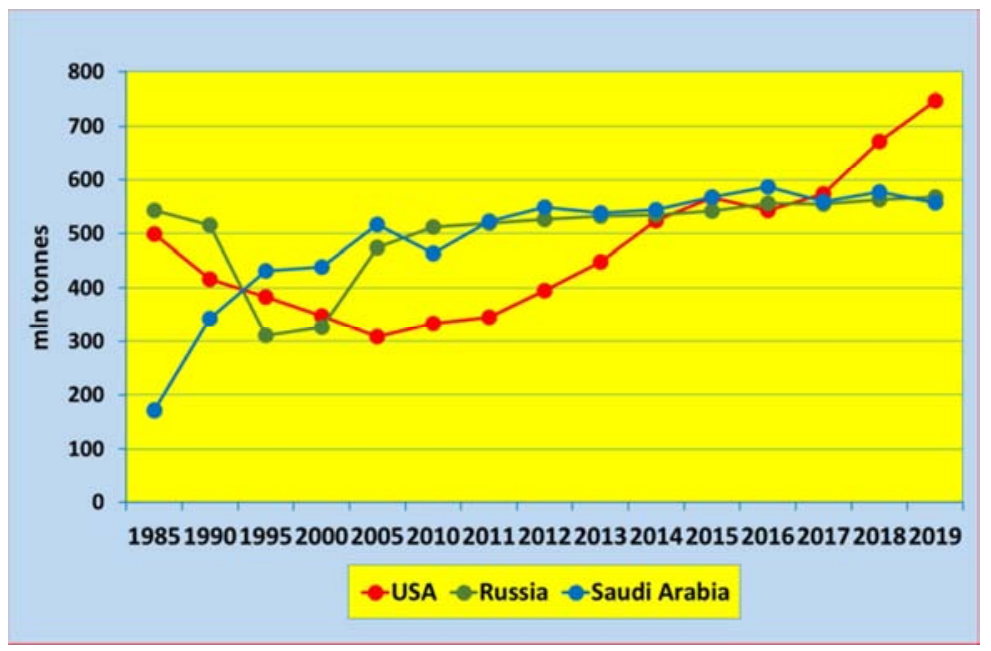

Source: compiled and drawn by the author based on https//: BP Statistical Review of World Energy June 2020 [4]

Figure 4. Annual Crude Oil and Field NGLs Production in the USA, Russia and Saudi Arabia in 1985-2019, in mln tonnes.

\subsection{Russia}

At the end of 2016, according to the Russian statistical agency (Roskomstat), the country once again became the world's largest oil producer, having outstripped in December Saudi Arabia (10.509 mln b/d compared with $10.424 \mathrm{mln} \mathrm{b/d}$ in November vs. 10.474 and $10.623 \mathrm{mln}$ b/d in Saudi Arabia) [5] (see also Table 3).

\subsubsection{Current Status}

As per the well-informed US Energy Information Administration (EIA/DoE), Russia's production of crude oil + lease condensate was on the average (in $\mathrm{kb} / \mathrm{d}$ ) as follows: in $2015-10,551$, in $2016-10,580$, in $2017-10,759$ and in
$2018-10,847[6]$.

Table 1. Production of Crude Oil and Lease/Mixed Condensate in Russia in 2016-2020 (according to the CDU/RF Minenergo).

\begin{tabular}{lll}
\hline & Mln tonnes & Mln b/d \\
\hline 2016 & 547.5 & 10.965 \\
2017 & 546.8 & 10.985 \\
2018 & 555.84 & 11.166 \\
2019 & 560.2 & 11.246 \\
2020 & 470.22 & $9.414 \mathrm{E}$ \\
$2016-2020$ & 2680.36 & $10.755 \mathrm{E}$ \\
\hline
\end{tabular}

Source: compiled and calculated on the basis of Ministerstvo energetiki RF https://minenergo.gov.ru/activity/statistic [7] 


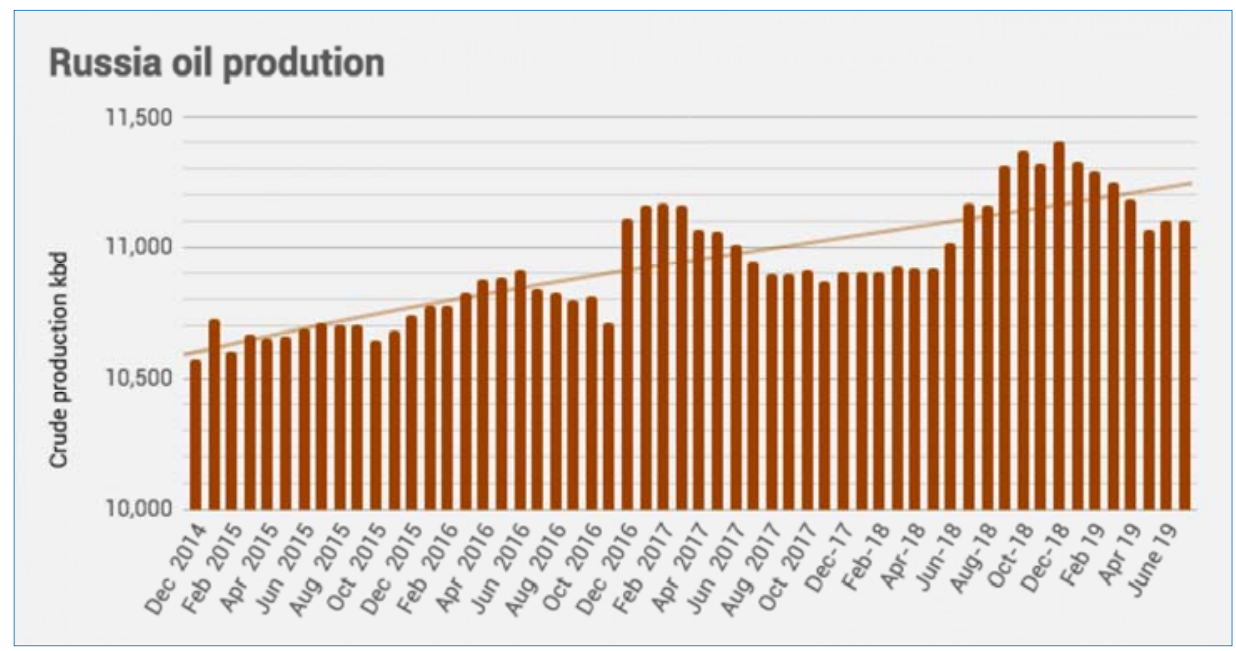

Sourse: https://www.themoscowtimes.com/2019/08/07 [6]

Figure 5. Monthly Crude Oil and Field Condensate Production in Russia in 2014-2019, in kb/d.

\subsubsection{A Bit of History}

Talking about the history, Russia's oil production reached its peak in 1987 (11,416 mln b/d of field oil, according to BP) before a great dip of the $90 \mathrm{~s}$, caused by total disorganization of the industry (and the national economy), - down to less than 6 $\mathrm{mln} \mathrm{b} / \mathrm{d}$ in the second half of the $90 \mathrm{~s}$ (Figure 6).

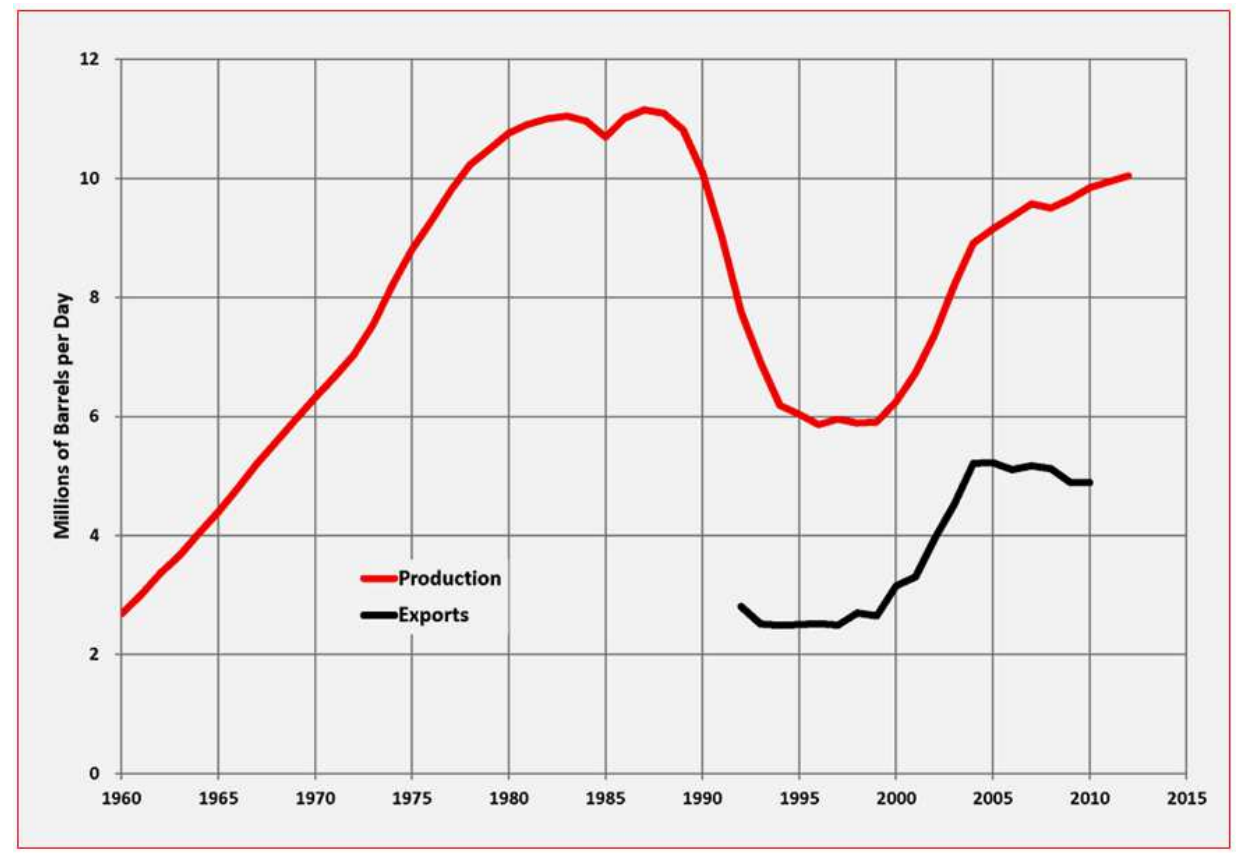

Source: Russian crude oil production https://en.wikipedia.org/wiki/Petroleum_industry_in_Russia\#/media/File: Russia_Oil_Production [9].

Figure 6. Russian Oil Production and Exports in 1960-2015, in mln b/d.

It is noteworthy that remaining oil reserves of Russia are considered hard-to-recover ones and are located quite unevenly. In 2019 , up to $80 \%$ of Russia's reco-verable oil reserves was associated with operating oil fields while a share of hard-to-recover oil reserves was estimated by Russia's Minprirody at 60\% [10]. Most of oil reserves is concentrated at 11 unique ( $\geq 300 \mathrm{mln}$ tonnes per Russian classification) and 179 large $(\geq 30 \mathrm{mln}$ tonnes of recoverable oil) fields of mainly the Khanty-Mansi autonomous okrug
(KhMAO), in the Western Siberia, which contain as a total some $70 \%$ of reserves and account for two thirds of oil production in the country [11].

Russian oil production was growing despite Russia participated in the so-called OPEC + deal. It is well known that, in December 2016, 24 oil producers (13 OPEC members and 11 non-member countries) had struck a deal to withdraw from the world oil market since the start of $20171.8 \mathrm{mln} \mathrm{b/d}$ of their combind oil production (compared with October 2016) to buoy 
up the declining world oil prices. Russia pled-ged to cut its oil production by $300 \mathrm{~kb} / \mathrm{d}$ (but I wonder which Russian profitably oil-producing company was about to do it as it was the promise of the Russian officials who - by law - have no right to regulate an entity's output... Neither it would be possible to command any decrease in national oil production as the oil industry in Russia is currently almost entirely privatized ...) while Saudi Arabia - the leading cutter - obliged to reduce its national oil production by $486 \mathrm{~kb} / \mathrm{d}$. The accord was extended several times and its terms were changed depending on the market's status. In particular, it was decided until the end of 2019 to decrease the collective oil production by $1.2 \mathrm{mln} \mathrm{b} / \mathrm{d}$ (compared with October 2018) while the combined cut in the first quarter of 2020 was set at $1.7 \mathrm{mln} \mathrm{b} / \mathrm{d}$.

In December 2019, Russia managed to exclude gas condensate from the agreement's all national pleges to make them in line with the OPEC quotas. As a result, at the end of 2019 , the RF should lower its oil output by from a new basic level of $10.626 \mathrm{mln} \mathrm{b/d}$ (instead of $11.421 \mathrm{mln} \mathrm{b/d}$ of crude and field condensate) while in the 1Q of 2020 - only by 300 $\mathrm{kb} / \mathrm{d}$ [12]. Moreover, the practical difficulty lies in the fact that neiter the Roscomstat, the Russian statistical state agency, nor the CDU TEK, the RF Minenergo's official information service, report Russian oil production excluding condensate...

Furthermore, at least since the beginning of 2020, the RF Minenergo started to falsify Russian oil production data to make them more consistent with the OPEC + pledge.

\subsection{Saudi Arabia}

With its some $260+$ remaining known oil reserves is the world's largest holder of conventional oil and can keep production at $12 \mathrm{mln} \mathrm{b} / \mathrm{d}$ until at least 2033 .

\subsubsection{Current Situation}

As for the recent years, the omniscient U.S. Energy Information Administration of the US Minenergo (EIA/DoE) determines it in Saudi Arabia as follows (in kb/d, average): 2015 - 10,168; 2016 - 10,461; 2017 - 10,134; 2018 - 10,425 and 2019 (showing an obvious decrease) - 9,826 [13].

As for the kingdom's quarterly field oil production, it, according to the US EIA/DoE, has gone down from 9,884 $\mathrm{mln} \mathrm{b/d} \mathrm{in} \mathrm{the} \mathrm{last} \mathrm{quarter} \mathrm{of} 2019$ to $8,821 \mathrm{mln} \mathrm{b/d} \mathrm{in} \mathrm{the} 3 \mathrm{Q}$ of 2020 (Figure 7).

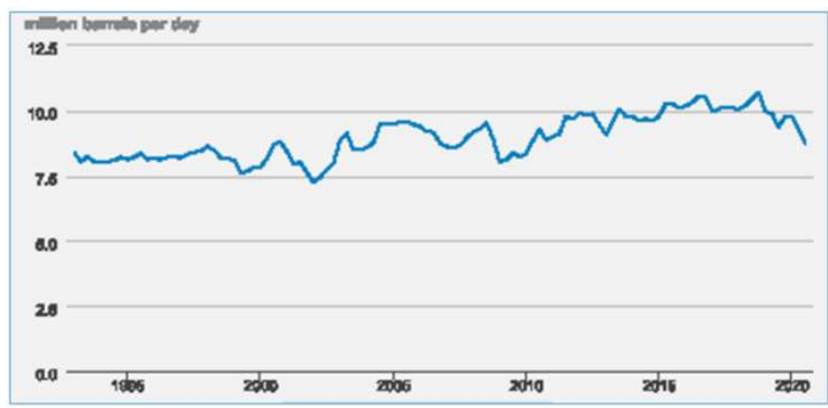

Figure 7. Quarterly Production of Crude Oil + Field Gas Condensate in Saudi Arabia in 1992-2020 (according to EIA), in $\mathrm{mln}$ b/d.

Source: https:/www.eia.gov/international/data/world/petroleum-and-otherliquids/quarterly-petroleum-and-other-liquids-production/SA Q [14]

According to the London-based CEIC Data services, Saudi Arabia's produc-tion of crude oil (that is excluding condensate or other field NGLs) in November 2020 was only $8.963 \mathrm{~kb} / \mathrm{d}$ (Figure 8).

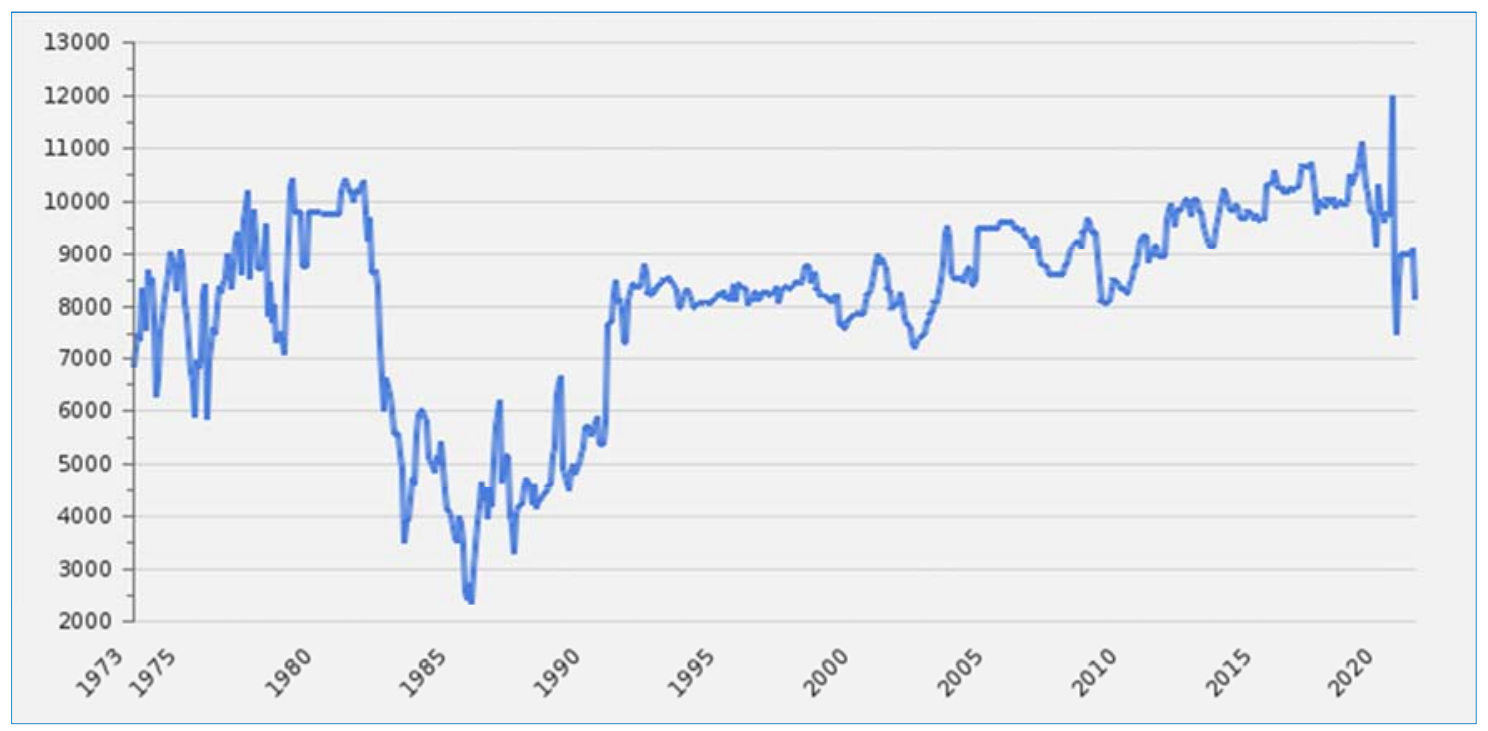

Source: https://take-profit.org/en/statistics/crude-oil-production/saudi-arabia [15]

Figure 8. Monthly Production of Crude Oil in Saudi Arabia in 1973-2020 (according to CEIC), in kb/d.

As it is known, Saudi Arabia restricts and curtails its oil output under actually self-imposed national production quotas and as an active participant of the OPEC + deal (see above).
Saudi oil production peaked in 2016 (at nearly $12.41 \mathrm{mln}$ $\mathrm{b} / \mathrm{d}$, according to BP), ranking 2nd in the world, and was annually lowering since. 


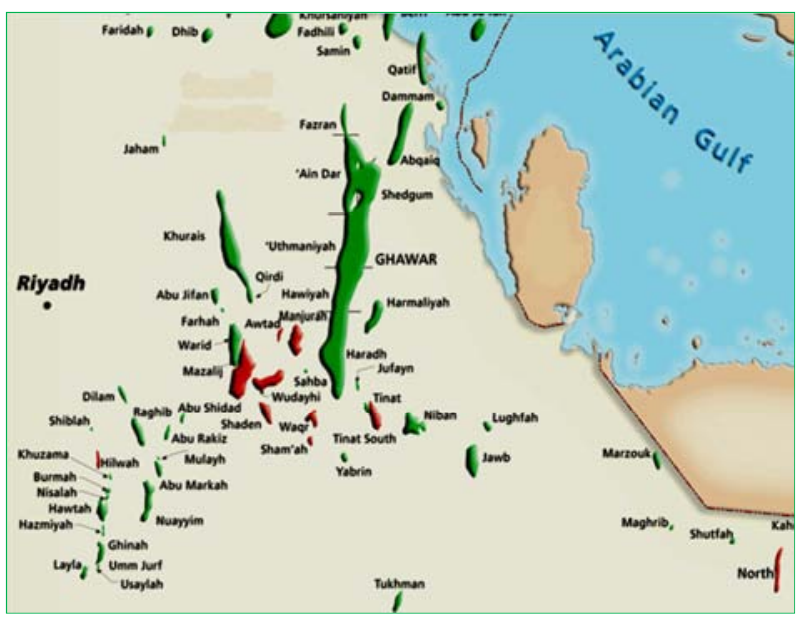

Figure 9. Location of Saudi Main HC Fields.

\subsubsection{Main Fields}

Current Saudi production comes mostly from five giant but aging and fast-depleting oilfields (Ghawar, Safaniya, Hanifa, Khurais and Zuluf), all of which are more than 70 years old and are being kept producing by a huge injection of water. They have over the years accounted for more than $90 \%$ of Saudi oil production with the Ghawar field providing some half of the total [3].

Ghawar, in the Eastern Province, is the largest conventional oil field in the world located at $280 \mathrm{~km} \times 30$ $\mathrm{km}$. It was discove-red in 1948, started production in 1951, and is owned and operated by Saudi Aramco. Some sources claim that the Ghawar peaked in 2005, though this is denied by the field ope-rators. The field holds estimated 170 billion barrels of original oil in place (OOIP), with some $140 \mathrm{bln} \mathrm{bbl}$ being regarded as recoverable [16].

\subsubsection{Production Capacity}

Saudi Arabia has the world's largest spare capacity in oil production and used to utilize it for being a swing oil producer within the OPEC (as well as globally) (Table 2).

Table 2. Oil Production Capacity and Production in Selected Countries (in April 2020 and as of the start of 2020), in kb/d. (1) April production vs recent peak. (2) Assumes $400 \mathrm{~kb} / \mathrm{d}$ from Saudi-Kuwait Neutral Zone

\begin{tabular}{lll}
\hline & Spare capacity, in kb/d & \\
\cline { 2 - 3 } & Immediately available (1) & Additional available by January 2020 (2) \\
\hline Saudi Arabia & 1,190 & 200 \\
UAE & 270 & 180 \\
Iraq & 120 & 260 \\
Kuwait & 200 & 0 \\
Russia & 220 & 150 \\
Subtotal & 2,000 & 790 \\
& Production in April, in kb/d & Potential Downside, in kb/d \\
Iran & 2,750 & -650 \\
Venezuela & 850 & -500 \\
Subtotal & 3,600 & $-1,150$ \\
\hline
\end{tabular}

Source: Oil Supply Crunch to Test OPEC's Spare Capacity https://www.oilandgas360.com/oil-supply-crunch-to-test-opecs-spare-capacity [17]

\subsubsection{Outlook}

The future of the kingdom's oil production is, however, quite gloomy, which is felt even now. Due to natural depletion of discovered oil fields and the recent lack of major discoveries in the country, its oil output goes down, which is especially the case for the foreseeable future. Unsurprisingly, already in 2007 some Western oil analysts (particularly, Euan Mearns of the University of Aberdeen) foresaw Saudi Arabia's an-nual oil output going down to some $6 \mathrm{mln}$ b/d by the end of the 20 s from the pre-dicted peak of nearly $12 \mathrm{mln}$ b/d in around 2011 (Figure 8).

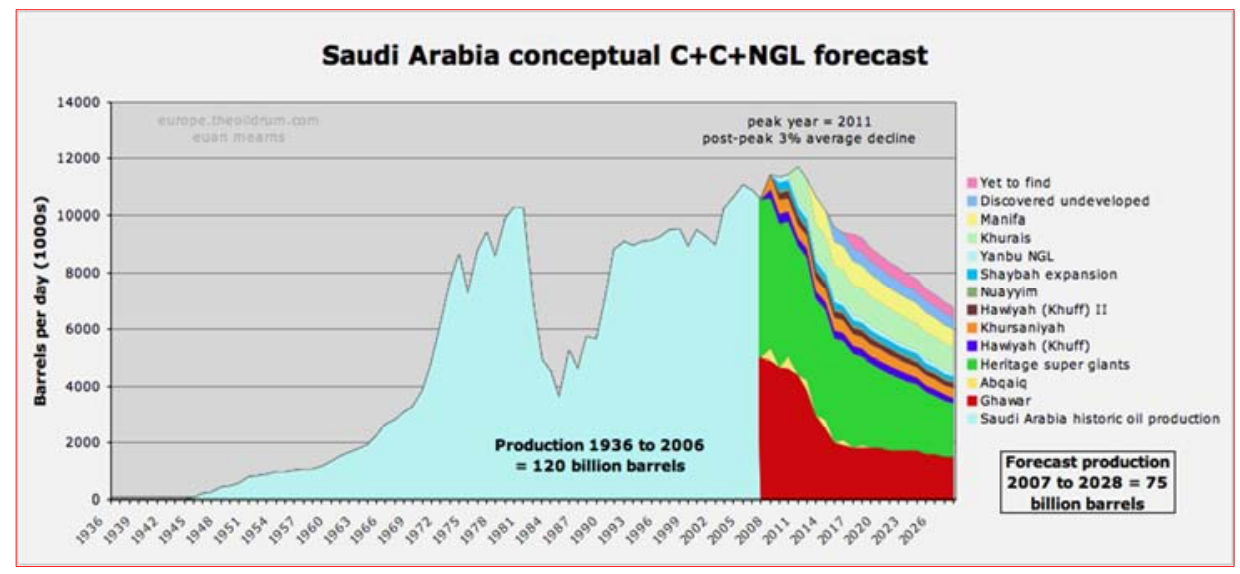

Source: http://heoildrum.com/node/9321 [18]

Figure 10. Oil Production in Saudi Arabia in 1936-2028, in kb/d. 
Back in the beginning of 2020, there were quite difficult negotiations on production cuts between Saudi Arabia and Russia within the OPEC+ deal (see above), which were immediately labeled by Western journalists as the price war. In fact, there was no war as such, simply Russian officials did not agree with initially recommended cuts (and the deal was crucially at stake) but the impasse had ended in April 2020 and the OPEC + agreement was extended further, with the pleged cuts of nearly $10 \mathrm{mln} b / \mathrm{d}$ [19]. As a result, average spot price of Brent blend and of Dubai and WTI crudes has gone up from some $\$ 3 / \mathrm{bbl}$ at end-April and got stabilezed at around $\$ 40 / \mathrm{bbl}$ in the $3 \mathrm{Q}$ of 2020 (Figure 12).

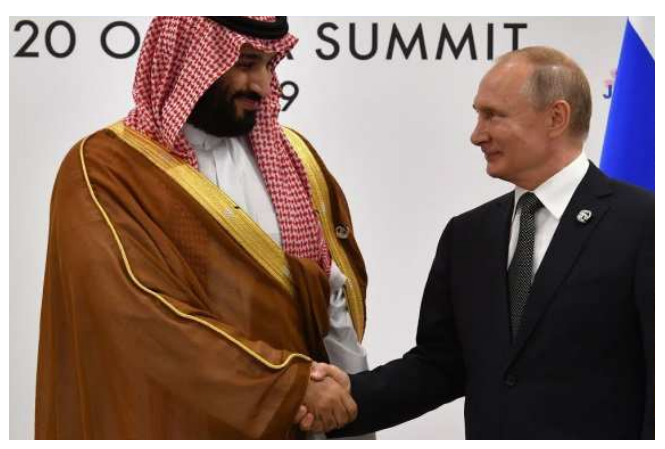

Figure 11. Friendly Meeting of Saudi and Russia Leaders in April 2020.

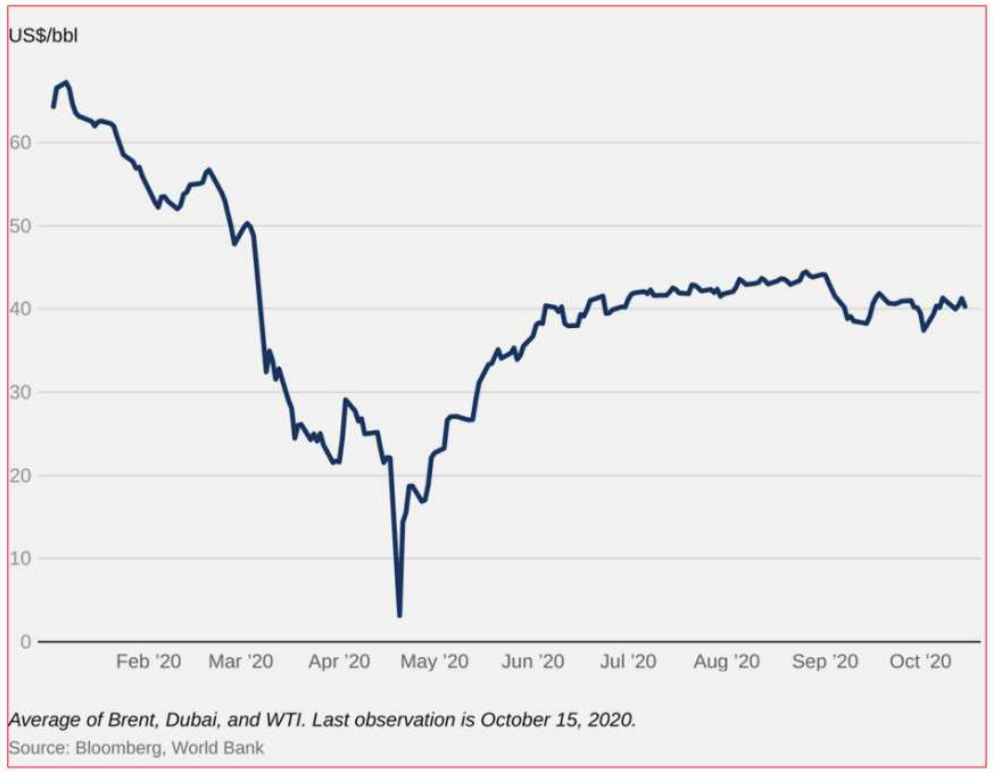

Source: https://img.datawrapper.de/JDTXk/full [20]

Figure 12. Dynamics of Average Spot Price of Brent, Dubai and WTI Oils in January-October 2020, in US\$/bbl.

Saudi Arabia's economy relies heavily on petroleum. According to the Forbes magazine, petroleum accounts for roughly 87 percent of the country's budget reve-nues, 32 percent of GDP, and 81 percent of export earnings [21]. A look at the dis-tribution of global oil reserves by country shows that only Venezuela possesses a higher share in global oil reserves than this Arab state [22].

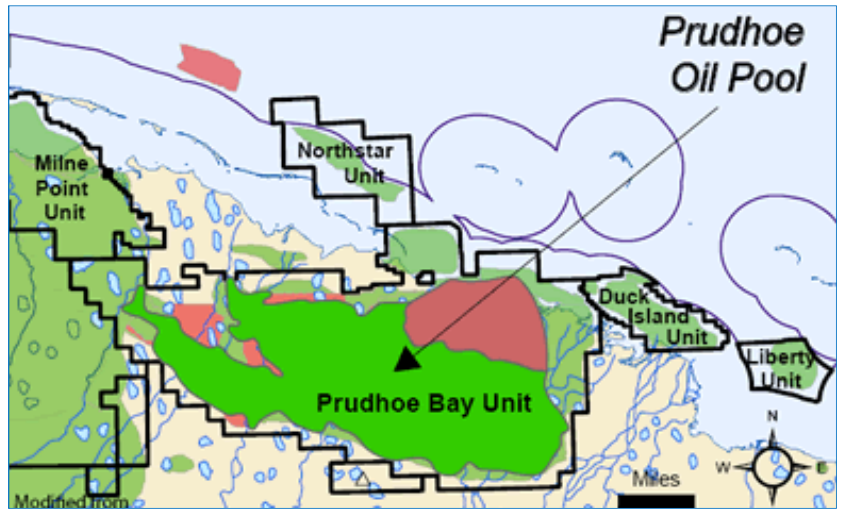

Figure 13. Location of the Prudhoe Bay Field.

\section{3. $U S A$}

In October 2018, thanks to aggressively growing "shaleoil" (tight-oil) production, the country, which produced in that month as a total $11,554 \mathrm{~kb} / \mathrm{d}$ of crude oil and lease condensate, according to the EIA [23], has become the world's largest oil producer, having overtaken this world supremacy status from Russia (see also Table 3).

\subsubsection{Where}

The largest oil-producing fields (forma-tions) in the USA include the Permian in Texas and in New Mexico, the Eagle Ford Shale in Texas, and the Bakken formation in North Dakota and Montana, Prudhoe Bay field in northern Alaska (by the way, the largest oil field in both the United States and North America, discovered in 1967 and located at 213,543 acres), the Wattenberg Field in Colorado (producing both gas and oil), the Shenzi field in the Gulf of Mexico, the Kuparuk River field in northern Alaska, west of the Prudhoe Bay, the Midway-Sunset oil field in California, the Atlantis oil field in the Gulf of Mexico, and Sugarkane field in Texas (Figure 14). 


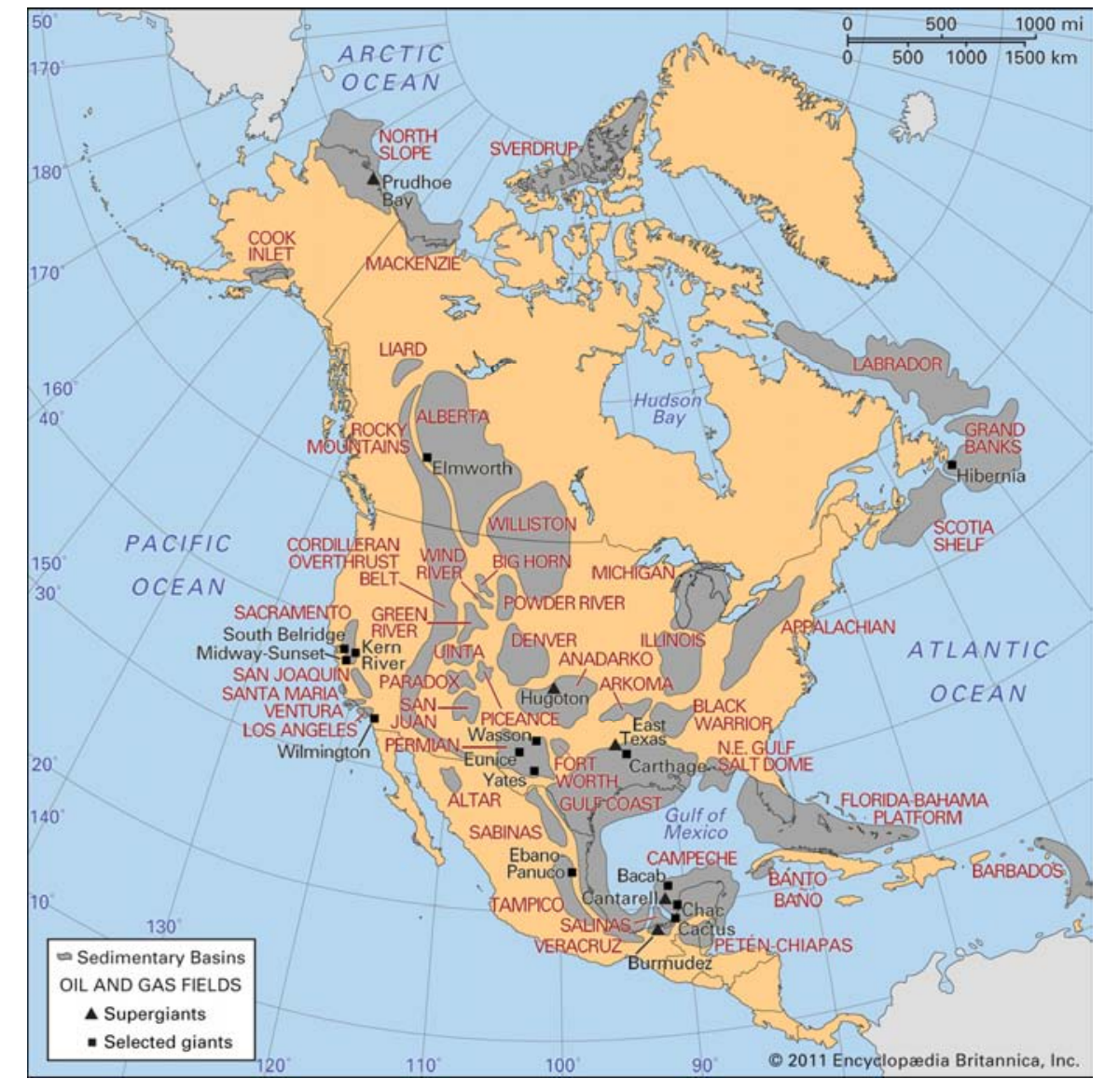

Source: https://www.britannica.com/science/petroleum [24]

Figure 14. Main Petroleum Sedimentary Basins and Fields of North America.

All in all, 100 top oil fields/formations account for over $55 \%$ of the country's proved oil reserves (more than 26.5 bln bbl out of $47.1 \mathrm{bln}$ bbl at the end of 2018) and nearly half of its oil production [23].

\subsubsection{Prospects}

As per the EIA, average field oil production in the USA actually was (in kb/d) 12,781 in 2015, 8,852 in 2016, 9,371 in 2017, 10,964 in 2018 and 12,248 in 2019 [25] and was predicted at the very end of 2020 - under a reference scenario - to go slightly down by 2050 to $11.96 \mathrm{mln} \mathrm{b/d}$. Included was the tight-oil production, which was $7.99 \mathrm{mln} \mathrm{b/d}(65 \%$ of the total) in 2019 and $8.74 \mathrm{mln} \mathrm{b/d} \mathrm{(73 \% )} \mathrm{in} 2050$ [26].

Within its near-term forecast, EIA expects U.S. field crude oil production to fall from the average 12.25 million $\mathrm{b} / \mathrm{d}$ in 2019 to 11.3 million $\mathrm{b} / \mathrm{d}$ in 2020 and $11.1 \mathrm{mln} \mathrm{b/d} \mathrm{in} 2021$ (Figure 15) [27, 28].

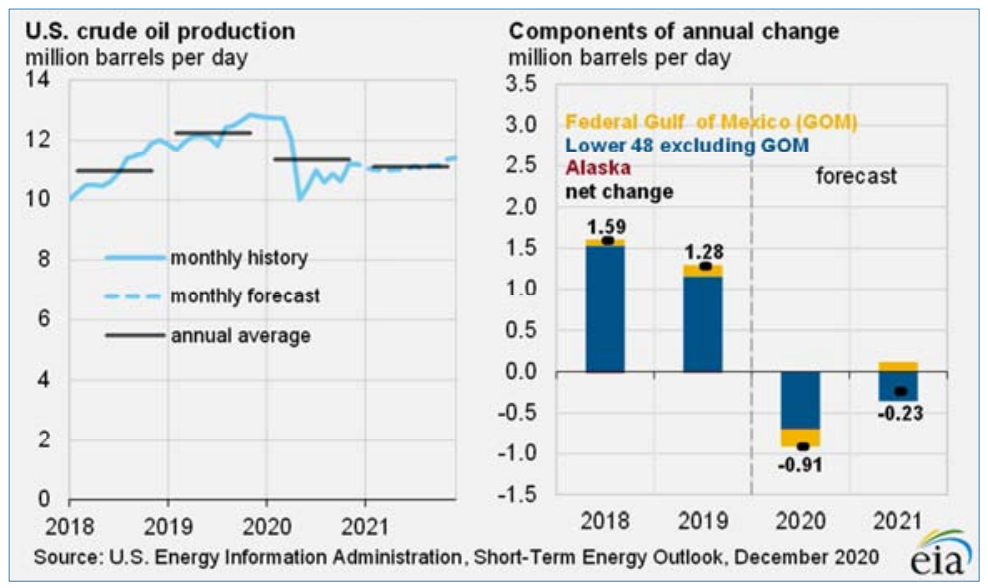

Source: https://www. eia.gov/outlooks/steo/report/us_oil [27]

Figure 15. Forecast Field Oil Production in the USA during 2020-2021, in $\mathrm{mln}$ b/d. 
Moreover, the estimated pandemic-driven 0.8 million bpd year-over-year out-put fall in 2021 is the largest annual decline in US crude oil production on record, the EIA says [28].

At any rate, "shale-oil" (tight-oil) production was instrumental in rising US total oil output up to and over $10 \mathrm{mln}$ $\mathrm{b} / \mathrm{d}$ - while conventional oil production was rougfly stable - at around 4,000-5,000 kb/d, - tight-oil one was dramatically increasing with only inconsiderable decrease during an obvious fall of domestic oil prices in 2014-2016 (Figure 16).

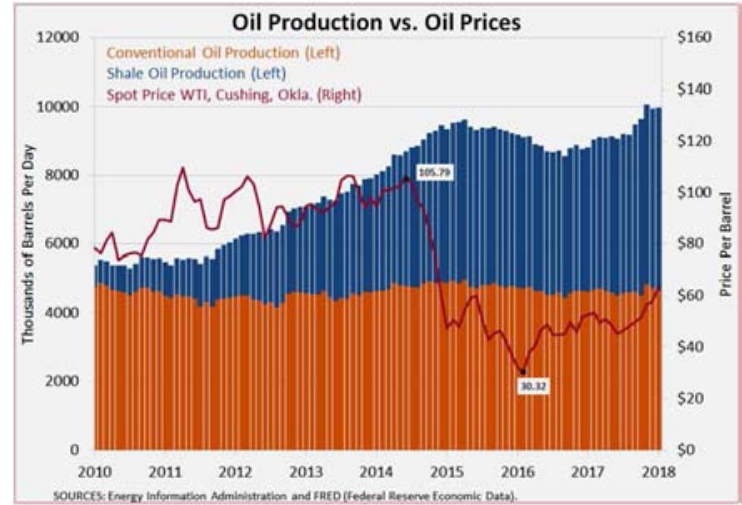

Source: https://www.stlouisfed.org/on-the-economy/2018/may/rise-shale-oil [29]

Figure 16. US Oil Production in 2010-2018, in $\mathrm{kb} / \mathrm{d}$.

\section{What Should Be Noted}

It is important not to overlook the fact that available oil production data usually relate to the production of crude oil + lease (or mixed/field) condensate.

Bearing in mind the differencies in measuring oil volumes at standard tempera-ture and pressure (or, shortly, STP), which are currently accepted in Russia and the USA (and actually worldwide, excluding Russia and some major buyers of Russian crude), it noteworthy that in order of bringing the Russian oil volumes (traditional-ly and officially measured at $20^{\circ} \mathrm{C}$ and $760 \mathrm{mmHg}$ ) to the US conditions $\left(60^{\circ} \mathrm{F}\right.$ and and 14.696 psia) one needs to decrease the Russian volume by $1.54 \%$ (Figure 17) [30].

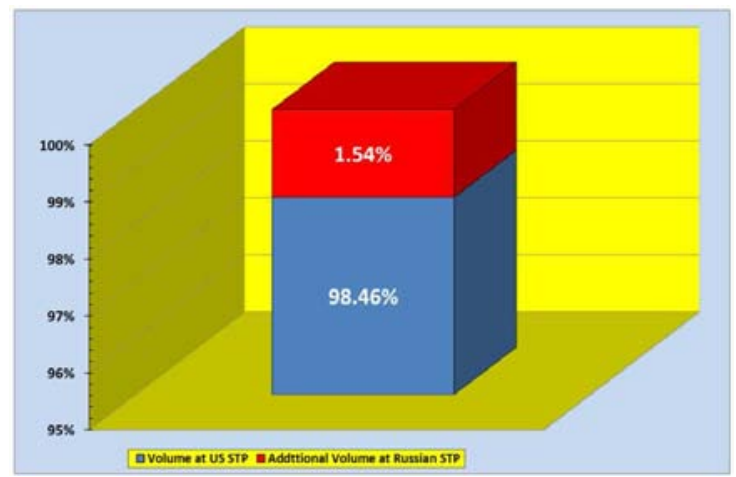

Figure 17. Oil Volumes under the U.S. and Russian Current STP, in \%.

Source: Khartukov, E. and Novak, A. Measuring Oil and Gas Volumes in Different Countries: The USA and Russian Cases. - Oilman, JanuaryFebruary 2021, pp. 28-30 [30]

\section{Who Is the Leader}

All in all, if we consider a period since the middle of the 80 s, when oil production data for Russia started to be published, and typical field oil production data (that of crude oil + lease condensate), the world's largest oil producer varied as follows: until 1992 it was Russia, then until 2009 a status of the biggest oil-producing country was surely held by Saudi Arabia, then again - for a short time, until 2011 - it was overtaken by Russia, in 2011 Saudi Arabia anew though shortly has acquired the status of the world's oil leader, in 2016 this status has moved from the USA for two years only back to Russia and finally since 2018 the USA have become the world's largest oil producer - thanks to their fast-growing tight-oil pro-duction - for how long?.. (Table 3).

Table 3. Annual Field Oil Production by the World's Largest Oil-Producing Countries in 1985-2020, in kb/d.

\begin{tabular}{|c|c|c|c|}
\hline Year & USA & Russia & Saudi Arabia \\
\hline 1985 & 10,580 & 10,863 & 3,601 \\
\hline 1986 & 10,231 & 11,247 & 5,208 \\
\hline 1987 & 9,944 & 11,416 & 4,450 \\
\hline 1988 & 9,765 & 11,373 & 5,656 \\
\hline 1989 & 9,159 & 11,070 & 5,636 \\
\hline 1990 & 8,914 & 10,342 & 7,106 \\
\hline 1991 & 9,076 & 9,264 & 8,820 \\
\hline 1992 & 8,868 & 7,978 & 9,092 \\
\hline 1993 & 8,583 & 7,119 & 8,893 \\
\hline 1994 & 8,389 & 6,371 & 8,983 \\
\hline 1995 & 8,322 & 6,236 & 8,974 \\
\hline 1996 & 8,295 & 6,062 & 9,087 \\
\hline 1997 & 8,269 & 6,171 & 9,005 \\
\hline 1998 & 8,011 & 6,110 & 9,267 \\
\hline 1999 & 7,731 & 6,119 & 8,524 \\
\hline 2000 & 7,733 & 6,583 & 9,121 \\
\hline 2001 & 7,670 & 7,106 & 8,935 \\
\hline 2002 & 7,624 & 7,755 & 8,207 \\
\hline 2003 & 7,368 & 8,602 & 9,628 \\
\hline 2004 & 7,250 & 9,335 & 10,306 \\
\hline 2005 & 6,901 & 9,598 & 10,839 \\
\hline 2006 & 6,825 & 9,834 & 10,671 \\
\hline 2007 & 6,857 & 10,057 & 10,269 \\
\hline 2008 & 6,783 & 9,965 & 10,655 \\
\hline 2009 & 7,267 & 10,152 & 9,709 \\
\hline 2010 & 7,558 & 10,379 & 9,865 \\
\hline 2011 & 7,883 & 10,533 & 11,079 \\
\hline 2012 & 8,926 & 10,656 & 11,622 \\
\hline 2013 & 10,099 & 10,807 & 11,393 \\
\hline 2014 & 11,801 & 10,860 & 11,519 \\
\hline 2015 & 12,781 & 11,007 & 11,998 \\
\hline 2016 & 8,852 & 10,551 & 10,461 \\
\hline 2017 & 9,371 & 10,580 & 10,134 \\
\hline 2018 & 10,964 & 10,759 & 10,425 \\
\hline 2019 & 12,248 & 10,847 & 10,145 \\
\hline 2020 & $11,100 \mathrm{~F}$ & $9,414 \mathrm{E}$ & $9,140 \mathrm{E}$ \\
\hline
\end{tabular}

Note: 1985-1999 - production of crude oil + field NGLs, according to BP; from 2000 - field production (crude oil + lease/field condensate), according to the EIA

Source: compiled by the author based mainly on https//: BP Statistical Review of World Energy June 2020 [4] and https://www.eia.gov/international/data [6] 


\section{No NGL}

However, if we consider only crude oil (that is exclude lease/field condensate or any other NGLs, a lot of which is produced in Russia - on the average, some $0.75 \mathrm{mb} / \mathrm{d}$ in the recent years or around $7 \%$ of its total oil output - and in the USA - $5.4 \mathrm{mb} / \mathrm{d}(0.44 \%)$ in 2019) [23], some differencies in the world's supremacy in 1985, 1991, 2014-2015 and 2018 occur but they, though important for those years, do not considerably change the general picture (Figure 19).

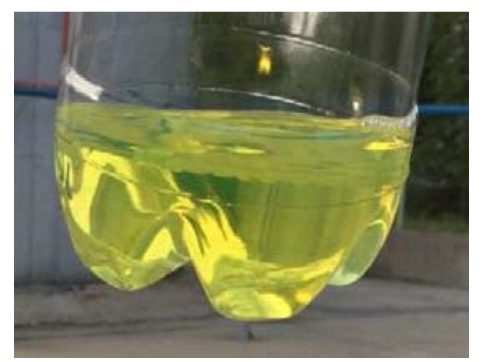

Figure 18. It is how NGLs look.

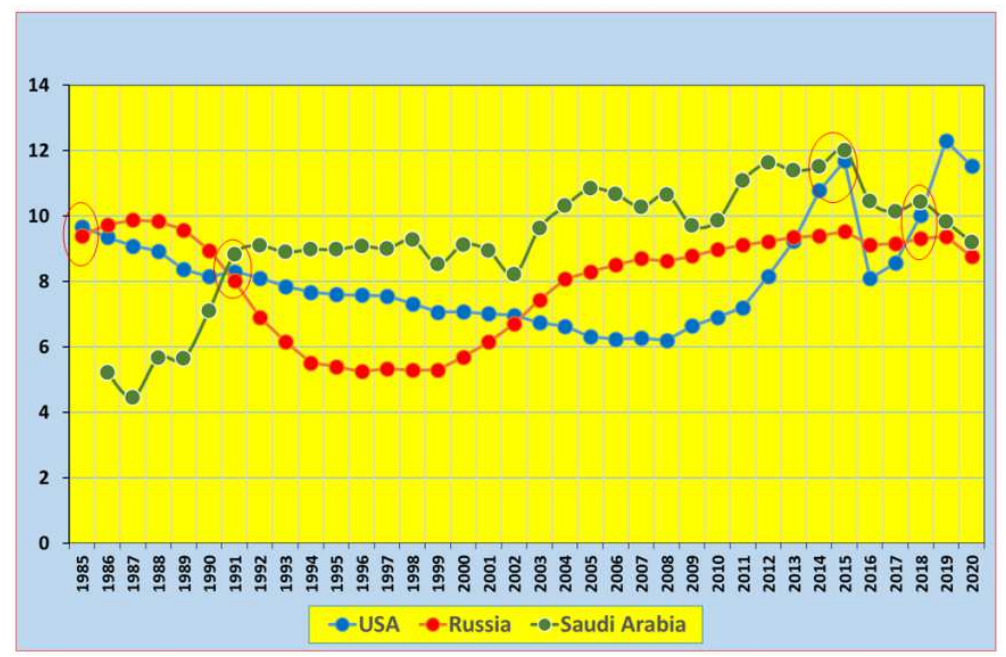

Figure 19. Annual Production of Field Oil by the World's Largest Oil-Producing Countries in 1985-2020, in kb/d.

Source: estimated and drawn by the author mainly based on Table 3, https://take-profit.org/en/statistics/crude-oil-production/saudi-arabia [15], https://www.eia. gov/dnav/pet/hist/LeafHandler.ashx?n=PET\&s=MCRFPUS1/2\&f [23]

\section{Outlooks Thoughout 2050}

In line with the last annual report of the interna-tional peak-oil organization (ASPO), the 3 top oil producing countries will produce by 2050 slightly less of their oil (Figure 20).

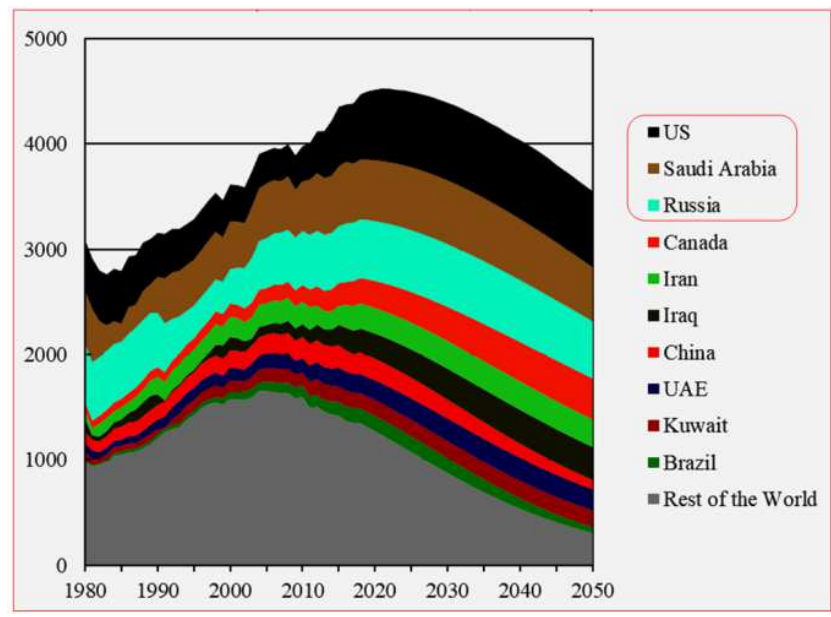

Source: http://peakoilbarrel.com/world-oil-2018-2050 [31]

Figure 20. Actual and Projected Field Oil Production in 1980-2050, in mln tonnes.

\subsection{USA}

According to the last long-term forecast (the beginning of 2021) of the Energy Information Administration of the US Department of Energy (EIA/ DoE), field oil production in the country must decrease by 2050 , under a reference scenario, from a maximum of more than $14 \mathrm{mln} \mathrm{b/d}$ in 2027-2035 to a bit less than $12 \mathrm{mln} \mathrm{b/d} \mathrm{(Figure} \mathrm{21).}$

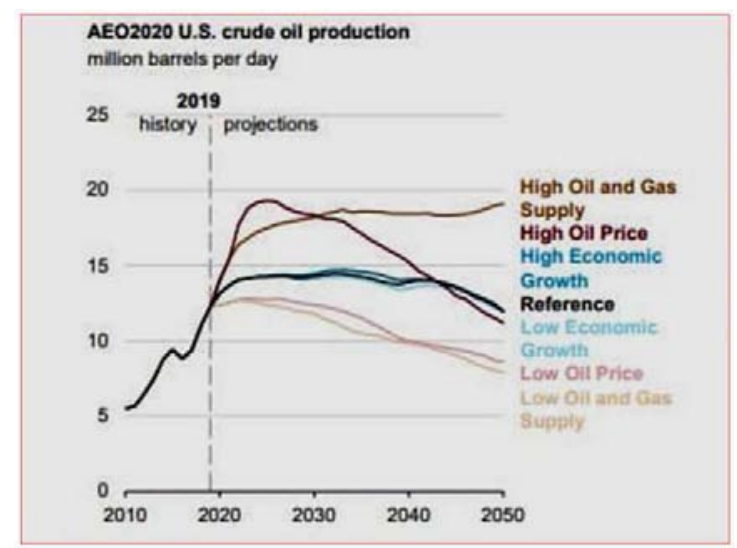

Figure 21. The USA's Field Annual Oil Production in 2010-2050 (according to EIA).

Source: Saudi Arabia Eyes Total Dominance In Oil https://oilprice.com/Energy/ Crude-Oil [3] 


\subsection{Russia}

As for Russia's long-term prospects, the Moscow-based Energy Research Institute of The Russian Academy of Sciences (ERI RAS) predicts oil pro-duction by 2040 in its basic scenario the following way (Figure 22):

\begin{tabular}{|c|c|c|c|c|c|c|c|}
\hline & 2010 & 2015 & 2020 & 2025 & 2030 & 2035 & 2040 \\
\hline N. America & 12,727 & 16,233 & 17,169 & 18,942 & 19,161 & 19,041 & 19,041 \\
\hline Canada & 3,187 & 3,804 & 3,864 & 5,597 & 6,832 & 7,111 & 7,170 \\
\hline Mexico & 2,908 & 2,689 & 2,131 & 1,992 & 1,593 & 1,593 & 1,574 \\
\hline USA & 6,633 & 9,720 & 11,194 & 11,353 & 10,736 & 10,337 & 10,278 \\
\hline S\& C America & 7,529 & 8,565 & 9,381 & 10,258 & 10,397 & 10,616 & 10,776 \\
\hline Venezuela & 2,908 & 3,107 & 3,107 & 3,207 & 3,286 & 3,306 & 3,326 \\
\hline Brazil & 2,211 & 3,207 & 4,242 & 4,940 & 5,059 & 5,159 & 5,238 \\
\hline Ecuador & 518 & 339 & 319 & 299 & 319 & 478 & 578 \\
\hline Others & 1,892 & 1,912 & 1,713 & 1,813 & 1,753 & 1,693 & 1,613 \\
\hline Europe & 3,904 & 2,908 & 3,247 & 3,087 & 2,788 & 2,649 & 2,629 \\
\hline Norway & 1,972 & 1,613 & 1,952 & 1,912 & 1,653 & 1,593 & 1,574 \\
\hline Great Britain & 1,255 & 817 & 757 & 717 & 717 & 657 & 637 \\
\hline Others & 697 & 478 & 558 & 438 & 398 & 398 & 418 \\
\hline FSU & 13,245 & 13,564 & 13,405 & 13,385 & 13,604 & 13,903 & 14,181 \\
\hline Russia & 10,058 & 10,397 & 10,218 & 10,058 & 9,780 & 9,481 & 9,322 \\
\hline Kazakhstan & 1,633 & 1,633 & 1,633 & 1,892 & 2,350 & 2,908 & 3,326 \\
\hline Azerbaijan & 1,016 & 1,016 & 1,036 & 996 & 1,036 & 1,036 & 1,056 \\
\hline Others & 558 & 498 & 518 & 438 & 458 & 458 & 498 \\
\hline Asia & 8,007 & 7,131 & 7,708 & 7,589 & 7,230 & 6,832 & 6,792 \\
\hline China & 4,043 & 3,784 & 4,402 & 4,083 & 3,864 & 3,506 & 3,525 \\
\hline India & 817 & 856 & 817 & 737 & 717 & 617 & 598 \\
\hline Aus. \& NZ & 498 & 478 & 478 & 538 & 558 & 617 & 677 \\
\hline Others & 2,649 & 2,012 & 2,012 & 2,251 & 2,091 & 2,111 & 1,992 \\
\hline Middle East & 24,240 & 26,869 & 29,200 & 30,255 & 32,725 & 34,159 & 34,956 \\
\hline Iran & 4,163 & 3,286 & 3,486 & 3,585 & 3,585 & 3,705 & 3,864 \\
\hline Iraq & 2,430 & 4,920 & 5,756 & 5,896 & 7,350 & 7,748 & 7,788 \\
\hline Saudi Arabia & 9,441 & 10,078 & 10,616 & 10,377 & 10,457 & 10,716 & 11,074 \\
\hline UAE & 2,649 & 3,207 & 3,386 & 3,326 & 3,446 & 3,386 & 3,227 \\
\hline Others & 5,577 & 5,378 & 5,975 & 7,071 & 7,907 & 8,585 & 9,003 \\
\hline Africa & 9,580 & 9,680 & 9,262 & 10,278 & 10,377 & 10,815 & 10,497 \\
\hline Egypt & 697 & 637 & 598 & 617 & 657 & 617 & 617 \\
\hline Libya & 1,554 & 1,733 & 1,773 & 1,693 & 1,992 & 2,211 & 2,390 \\
\hline Nigeria & 2,410 & 2,649 & 2,271 & 2,211 & 1,673 & 1,773 & 1,673 \\
\hline Angola & 1,813 & 1,434 & 1,394 & 1,872 & 1,992 & 1,872 & 1,793 \\
\hline Others & 3,107 & 3,227 & 3,207 & 3,864 & 4,063 & 4,342 & 4,043 \\
\hline OPEC & 33,203 & 36,709 & 38,641 & 40,095 & 42,684 & 44,656 & 44,715 \\
\hline Non-OPEC & 46,030 & 48,221 & 50,731 & 53,678 & 53,599 & 53,360 & 54,157 \\
\hline World & 79,233 & 84,930 & 89,371 & 93,773 & 96,283 & 98,016 & 98,872 \\
\hline
\end{tabular}

Source: http://peakoilbarrel. com/russias-take [32]

Figure 22. Oil + Lease Condensate Production in 2010-2040, in $\mathrm{mln}$ b/d (originally converted from tonnes using 7.27 barrels per tonne).

In its turn, the all-knowing EIA predicts, however, that Russian annual field oil production must go up by 2050 from less than $11 \mathrm{mb} / \mathrm{d}$ to more than $13 \mathrm{mb} / \mathrm{d}$ and Russia must overtake the USA in this respect (Figure 23).

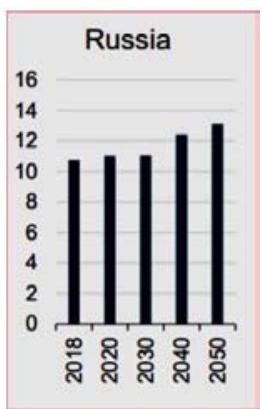

Figure 23. The EIA's Flrecast of Russia's Annual Field Oil Output till 2050, in $\mathrm{mln} b / d$.

Source: https://www.rt.com/business/469653-russia-overtakes-us-oilproduction [33]

\subsection{Saudi Arabia}

Based on the ASPO estimates, the Saudi oil production is projected to peak in 2030 at 606 million tonnes and to lessen to around $500 \mathrm{mln} \mathrm{t}$ per year by the middle of this century (Figure 24).

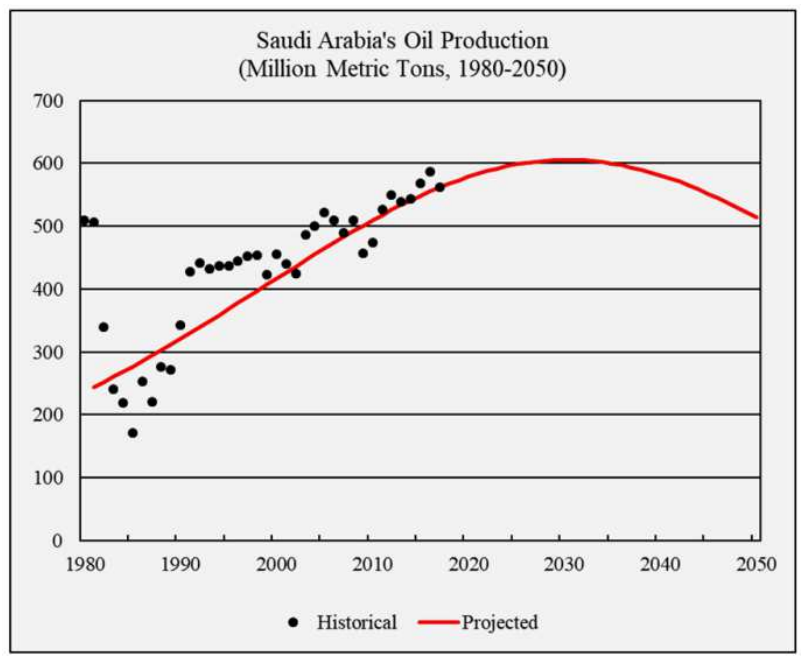

Source: http://peakoilbarrel.com/world-oil-2018-2050 [31]

Figure 24. Actual and Projected Annual Field Oil Production in Saudi Arabia in 1980-2050, in mln tonnes per year.

\section{Conclusion}

So, based on the above considerations, and if all field NGLs are included, currently, since 2019, the world's largest oil producer is the USA, fol-lowed by Saudi Arabia and Russia, and this is unlikely to change in near future.

\section{References}

[1] The United States has become the world's biggest crude oil producer ahead of Russia and Saudi Arabia [Available in the Internet at:

http://fingfx.thomsonreuters.com/gfx/editorcharts/OIL-

PRODUCTION] (Accessed 20 December 2020).

[2] Ten largest oil producers [Available in the Internet at: https://www.valuewalk.com/2020/06/largest-oil-producers2020] (Accessed: 13 January 2021).

[3] Saudi Arabia Eyes Total Dominance In Oil [Available in the Internet at: https://oilprice.com/Crude-Oil] (Accessed: 13 January 2021).

[4] Oil Production [Available in the Internet at: https//:BP Statistical Review of World Energy June 2020] (Accessed: 3 January 2021).

[5] Russia and Saudia have crossed hoses [Available in the Internet at: $\quad \mathrm{http} / / / \mathrm{sr}$.fondedin.ru/new/fullnews arch to.php? subaction=showfull \&id= 14913074 (Accessed: 31 December 2020).

[6] International - U.S. Energy Information Administration [Available in the Internet at: https://www.eia.gov/international/data] (Accessed: 31 December 2020). 
[7] Russian Oil and Gas Output Continues Rising Despite Setbacks [Available in the Internet at: https://www.themoscowtimes.com/2019/08/07] (Ac-cessed: 31 December 2020).

[8] Ministerstvo energetiki RF [Available in the Internet at: https://minenergo.gov.ru/activity/statistic] (Accessed: 1 January 2021).

[9] Russian crude oil production [Available in the Internet at: https://en.wikipedia.org/wiki/Petroleum_industry_in_Russia\#/ media/File:Rus-sia_Oil_Production (Accessed: 1 January 2021).

[10] Hard-to-recover oil reserves are estimated in the Minprirody [Available in the Internet at: https://www.dp.ru/a/2019/08/27] (Ac-cessed: 1 January 2021).

[11] Where there is more oil? [Available in the Internet at: https://www.cdu.ru/tek_russia/issue/2019/5] (Accessed: 1 January 2021).

[12] Rossiya postavila postsovetskiy record po dobyche nefti $\mathrm{v}$ 2019 g. [Available in the Internet at: https://neftegaz.ru/news/dobycha/516403] (Accessed: 1 January 2021).

[13] International - U.S. Energy Information Administration [Available in the Internet at: https://www.eia.gov/international/data] (Accessed: 1 January 2021).

[14] International - U.S. Energy Information Administration (EIA) [Available in the Internet at: https://www.eia.gov/international/data/world/petroleum-andother-liquids/quarterly-petroleum-and-other-liquidsproduction/SA Q] (Accessed: 1 January 2021).

[15] Saudi Arabia Crude Oil: Production [Available in the Internet at: $\quad$ https://take-profit.org/en/statistics/crude-oilproduction/saudi-arabia (Accessed: 1 January 2021).

[16] Ghawar Field [Available in the Internet at: https://en.wikipedia.org/wiki/Ghawar_Field] (Accessed: 1 January 2021).

[17] Oil Supply Crunch to Test OPEC's Spare Capacity [Available in the Internet at: https://www.oilandgas360.com/oil-supplycrunch-to-test-opecs-spare-capacity (Accessed: 1 January 2021).

[18] Tech Talk - The "Best of the Rest" in Saudi Arabia [Available in the In-ternet at: http://theoildrum.com/node/9321 (Accessed: 1 January 2021).

[19] OPEC + reaches deal to cut oil production by 9.7 million barrels per day [Available in the Internet at: https://edition.cnn.com/2020/04/12/energy/opec-dealproduction-cut (Accessed: 1 January 2021).

[20] Crude oil price rising [Available in the Internet at: https://img.data-wrapper.de/JDTXk/full (Accessed: 1 January 2021).

[21] Saudi Arabia - Market Overview [Available in the Internet at: https://www.export.gov/article?series=Country_Commercial_ kav (Accessed: 3 January 2021).
[22] Inflation in Saudi Arabia since 1985 [Available in the Internet at: https:/ /www.statista.com/statistics/268062] (Accessed: 3 January 2021).

[23] Petroleum \& other liquids [Available in the Internet at: https://www.eia.gov/dnav/pet/hist/LeafHandler.ashx?n=PET\& $\mathrm{s}=$ MCRFPUS1/2\&f (Accessed: 1 January 2021).

[24] Major-oil-producing-countries [Available in the Internet at: https://www.britannica.com/science/petroleum (Accessed: 1 January 2021).

[25] U.S. Field Production of Crude Oil [Available in the Internet at: https://www.eia.gov/dnav/pet/hist/LeafHandler.ashx?n=PET\& $\mathrm{s}=$ MCRFPUS-2\&f] (Accessed: 1 January 2021).

[26] Annual Energy Outlook (AEO): Evaluation of AEO2020 Reference Case Projections Oil and Gas Supply [Available in the Internet at: https://www. eia.gov/petroleum/supply (Accessed: 1 January 2021).

[27] Short-Term Energy Outlook [Available in the Internet at: https://www. eia.gov/outlooks/steo/report/us oil (Accessed: 26 December 2020).

[28] US crude oil production forecast to fall in 2020, 2021 [Available in the In-ternet at: https:/ /www.aa.com. tr/en/energy/stock-market] (Accessed: 26 December 2020).

[29] The Rise of Shale Oil 2021 [Available in the Internet at: https://www. stlouisfed.org/on-the-economy/2018/may/riseshale-oil] (Accessed: 3 January 2021).

[30] Khartukov, E. and Novak, A. Measuring Oil and Gas Volumes in Different Countries: The USA and Russian Cases. Oilman, January-February 2021, pp. 28-30.

[31] World Oil 2018-2050: World Energy Annual Report (Part 2) [Available in the Internet at: http://peakoilbarrel.com/worldoil-2018-2050] (Accessed: 13 January 2021).

[32] Global and Russian Energy Outlook to 2040 [Available in the Internet at:http://peakoilbarrel. com/russias-take] (Accessed: 13 January 2021).

[33] Russia will eclipse American oil production by 2050 - US energy agency https://www.rt.com/business/469653-russiaovertakes-us-oil-production] (Accessed: 13 January 2021).

\section{Biography}

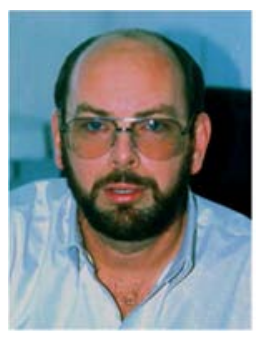

Eugene Khartukov, Professor of the Moscow State Institute/University for International Relations (MGIMO MFA), Head of the World Analyses and Forecasting Group (GAPMER) and of the Center for Petroleum Business Studies (CPBS) and Vice President (for Eurasia) of the Geneva-based PetroLogistics SA. Author of more than 360 publications oil, gas and energy forecasting and speaker at over 170 international energy and economic fora 